\title{
FENOMENA DAN KONSTRUKSI KOMUNIKASI MASYARAKAT DI SEKITAR TWA SORONG PAPUA BARAT
}

\author{
The Phenomenon and Construction of Community Communication \\ Around the TWA Sorong, West Papua
}

\author{
Mutiono $^{1, *}$ \\ ${ }^{1}$ Balai Besar Konservasi Sumber Daya Alam Papua Barat, Sorong Papua Barat 98417, Indonesia \\ ${ }^{*}$ E-mail: mas.muti1992@gmail.com
}

Disetujui: 20 April 2020 Publikasi Online: 21April 2020

\begin{abstract}
Management of conservation areas cannot be separated from the existence of the surrounding communities. One important aspect in understanding society is to know the construction of communication that develops in a community group. This study aims to uncover the phenomenon of communication that develops in the communities around TWA Sorong along with its construction as an implication of community interaction with the surrounding forest resources. This research is based on a constructivist paradigm with a qualitative approach. The strategy used is a case study strategy through observation, interviews and desk study methods. The results showed a symbolic convergence phenomenon that caused asymmetric information between the government and the community in the historical context of TWA Sorong and could lead to legal but not legitimate conditions. Symbolic convergence is strongly constructed by oral tradition communication and characteristics of village communities that are still strong with adat and customary rights.
\end{abstract}

Keywords : adat, customary right, oral tradition, symbolic convergence, TWA Sorong

\begin{abstract}
ABSTRAK
Pengelolaan kawasan konservasi, tidak dapat dilepaskan dari keberadaan masyarakat yang ada di sekitarnya. Salah satu aspek penting dalam memahami masyarakat adalah dengan mengetahui konstruksi komunikasi yang berkembang dalam suatu kelompok masyarakat. Penelitian ini bertujuan untuk mengungkap gambaran fenomena komunikasi yang berkembang pada masyarakat sekitar TWA Sorong beserta konstruksi pembentuknya sebagai implikasi interaksi masyarakat dengan sumber daya hutan di sekitarnya. Penelitian ini berlandaskan pada paradigma konstruktivis dengan pendekatan kualitatif. Adapun strategi yang digunakan adalah strategi studi kasus melalui metode observasi, wawancara dan desk study. Hasil penelitian menunjukkan adanya fenomena konvergensi simbolik yang menyebabkan adanya informasi tidak simetris antara pemerintah dengan masyarakat dalam konteks sejarah TWA Sorong dan dapat mengakibatkan terjadinya kondisi legal tidak legitimate. Konvergensi simbolik secara kuat dikonstruksi oleh tradisi komunikasi oral (oral tradition) dan karakteristik masyarakat perkampungan yang masih kuat dengan adat dan hak ulayat.
\end{abstract}

Kata kunci : adat, hak ulayat, konvergensi simbolik, tradisi oral, TWA Sorong

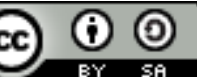

Content from this work may be used under the terms of the Creative Commons Attribution-ShareAlike 4.0 International License.. Any further distributionof this work must maintain attribution to the author(s) and the title of the work, journal citation and DOI.

Published under Department of Communication and Community Development Science, IPB University ISSN: 1693-3699 | EISSN: 2442-4102 


\section{PENDAHULUAN}

Komunikasi memegang peran penting dalam proses-proses pembangunan. Berdasar prosesnya, komunikasi pembangunan dapat berlangsung dengan struktur vertikal maupun horizontal sesuai konteksnya. Komunikasi pembangunan yang berlangsung melalui struktur vertikal cenderung berpotensi untuk terjadi adanya salah pengertian (miscommunication) dan ketidaksesuaian dengan kebutuhan pembangunan serta dapat menyebabkan tumbuhnya budaya bisu yang dapat mengarah pada dominasi serta ketimpangan (Mutiono et al., 2018). Oleh sebab itu, komunikasi pembangunan horizontal atau yang lazim disebut sebagai komunikasi pembangunan partisipatif menjadi mainstream dalam menjawab tantangan komunikasi pembangunan yang konvensional (Hadiyanto, 2008).

Komunikasi pembangunan, pada praktiknya dapat terkonstruksi ke dalam berbagai ragam kegiatan tergantung bentuk dan tujuan pembangunan yang akan diwujudkannya termasuk salah satunya adalah komunikasi pembangunan dalam pengelolaan sumber daya hutan. Kerusakan sumberdaya hutan akibat konflik berkepanjangan salah satu indikasinya disebabkan oleh konsep dan praktik pengelolaan sumber daya hutan yang dianggap cenderung anti sosial melalui komunikasi vertikal yang mendominasi (command and control) (Mutiono et al., 2018; Santoso, 2004). Oleh karena berbagai persoalan yang timbul akibat pengelolaan sumber daya hutan yang mempraktikkan komunikasi yang cenderung mendominasi, mulai sekitar tahun 1970an, gagasan-gagasan kehutanan yang lebih memokuskan diri pada aspek partisipatif mulai menarik perhatian berbagai kalangan (Santoso, 2004). Hal tersebut terungkap setidaknya dari berbagai tema yang diangkat dalam kongres kehutanan internasional yang lebih bernuansa sosial seperti forest for socio-economic development di Buenos Aires tahun 1972, forest for people di Jakarta tahun 1978, forest resources in the integral development of society di Mexico City tahun 1985, dan berbagai pertemuan-pertemuan lainnya baik skala nasional maupun internasional yang mulai membicarakan kehutanan dalam aspek sosial yang lebih partisipatif sehingga mulailah bermunculan berbagai istilah seperti community forestry, social forestry, farm forestry, village forestry, forestry for community development, community based forest management dan lain sebagainya (Santoso, 2004).

Konservasi bagi sebagian kalangan masih dipersepsikan bertentangan dengan aspek sosial yang cenderung partisipatif karena persoalan kerusakan sumber daya hutan dianggap disebabkan oleh keberadaan manusia yang cenderung amoral dalam menempatkan sumber daya hutan sehingga sebagian konservasionis lebih memilih memegang teguh prinsip perlindungan, pengawetan dan pemanfaatan lestari secara kaku dengan lebih mengutamakan aspek pengawasan, pelarangan dan penegakan hukum dengan dominasi negara yang kuat (Cahyono, 2013).

Adanya transformasi paradigma pengelolaan sumber daya hutan yang bergerak dari paradigma the forest first ke paradigma the forest second dengan salah satunya ditunjukkan melalui munculnya konsep 10 cara baru kelola kawasan konservasi yang diperkenalkan oleh Wiratno (2018) dalam bukunya 10 Cara Baru Kelola Kawasan Konservasi di Indonesia: Membangun "Organisasi Pembelajar", menunjukkan bahwa pengelolaan kawasan konservasi di Indonesia tidak lagi dapat dilakukan hanya melalui dominasi negara (command and control), melainkan perlu menekankan pendekatan partisipatif dengan memperhatikan berbagai aspek termasuk memahami fenomena komunikasi masyarakat yang tinggal di daerah penyangga kawasan.

Dalam tradisi kajian socio-cultural, fenomena komunikasi menjadi salah satu bagian penting untuk diperhatikan. Mengingat Tanah Papua merupakan salah satu wilayah dengan kebudayaan dan latar belakang sosial masyarakat yang sangat beragam dan rentan mendapatkan pengaruh sebagaimana diungkap Deda \& Mofu (2013) mengenai adanya transformasi sosial masyarakat Papua Barat dari sisi bahasa, kepemimpinan dan wilayah adat yang dipengaruhi oleh adanya intervensi eksternal, kemudian juga diungkap oleh Anakotta et al. (2019) yang menemukan bahwa akulturasi masyarakat yang cenderung negatif di Papua Barat dipengaruhi oleh adanya interaksi sosial dan mobilitas masyarakat yang tinggi, serta temuan Suryawan (2015) yang menemukan adanya rupturasi dan transformasi sosial budaya masyarakat Papua akibat intervensi komunikasi pembangunan yang dilakukan oleh struktur dominan di daerahnya yang lebih berbasis kapitalistik, seluruhnya menunjukkan adanya kecenderungan urgensitas dalam pentingnya memaknai fenomena komunikasi dalam proses-proses pengembangan masyarakat karena fenomena pergeseran budaya dan transformasi sosial sangat erat hubungannya dengan fenomena komunikasi.

Dalam konteks pengelolaan Taman Wisata Alam (TWA) Sorong yang tidak terlepas dari 
adanya kehidupan sosial budaya masyarakat Papua disekitarnya bahkan memiliki hubungan erat baik secara historis maupun kultural terhadap lahan dan hutan yang tumbuh diatasnya membuat prosesproses untuk memahami konteks fenomena komunikasi masyarakat setempat menjadi penting. Penelitian Mutiono (2020) telah menunjukkan adanya distorsi persepsi masyarakat dengan pengelola TWA Sorong dalam hal batas kawasan yang tidak lain didominasi oleh permasalahan komunikasi dalam proses komunikasi pembangunan pada TWA Sorong sejak awal ditunjuk oleh Menteri Pertanian tahun 1981. Proses-proses rekonsiliasi yang telah dilakukan juga oleh pengelola pada periode 20 tahun terakhir dalam memperoleh kesepakatan batas juga masih belum menemukan titik temu. Oleh sebab itu, penelitian ini bertujuan untuk mengungkap fenomena komunikasi masyarakat di sekitar TWA Sorong sebagai implikasi interaksi masyarakat dengan sumber daya hutan disekitarnya sehingga dapat diungkap konstruksi fenomena komunikasi yang membangun pembatas untuk diperolehnya titik temu rekonsiliasi penyelesaian batas oleh masyarakat dan pengelola TWA Sorong. Penelitian ini diharapkan mampu memberikan informasi mengenai gambaran fenomena komunikasi masyarakat di sekitar TWA Sorong beserta konstruksi yang membangunnya sehingga dapat digunakan sebagai bahan perumusan kebijakan pengelolaan kawasan yang lebih partisipatif.

\section{METODE}

Penelitian ini berlandaskan paradigma konstruktivis. Berangkat dari paradigma tersebut, pendekatan yang digunakan adalah pendekatan kualitatif karena berkaitan dengan fungsi memahami masalah yang belum jelas, mengetahui makna yang tersembunyi, memahami interaksi sosial, mengembangkan teori, memastikan kebenaran data dan untuk meneliti sejarah perkembangan (Darmadi, 2014). Strategi dari pendekatan kualitatif yang digunakan dalam penelitian ini adalah studi kasus. Dalam studi kasus, terdapat 3 elemen utama yang menjadi fokus penelitian, yaitu elemen tempat (place), pelaku (actors), dan aktivitas (activity) yang berinteraksi secara sinergi karena penelitian ini hanya ingin melihat sesuatu yang terjadi pada situasi sosial secara mendalam (Darmadi, 2014). Penelitian ini berfokus pada aktivitas komunikasi masyarakat di sekitar TWA Sorong dengan informan terdiri dari 7 warga Kampung $S$ dan 3 Pejabat dari instansi pengelola TWA Sorong yang diambil secara purposif dengan kriteria sebagai berikut:

1. Pemimpin/tokoh di Kampung S;

2. Pelaku sejarah pembentukan Kampung S;

3. Memiliki pengetahuan tentang sejarah Kampung S; dan/atau

4. Memiliki pengetahuan tentang sejarah TWA Sorong.

Analisis data pada penelitian ini menggunakan analisis deskriptif. Analisis deskriptif dilakukan untuk memperoleh deskripsi dari temuan-temuan penting yang telah dikumpulkan sehingga dapat diperoleh pemahaman (verstehen) dari fakta dan interpretasi fenomena yang ada di masyarakat sehingga dapat menjadi suatu susunan yang mudah dipahami. Analisis deskriptif akan diarahkan untuk menggali fenomena komunikasi yang ada pada masyarakat di sekitar TWA Sorong beserta konstruksi komunikasi yang membangunnya. Dalam proses analisis deskriptif, peneliti harus menerapkan prinsip triangulasi sebelum melakukan penyimpulan akhir dari proses analisis yang dilakukan. Triangulasi merupakan proses check dan recheck satu sumber bukti dengan sumber bukti lainnya. Ada beberapa kemungkinan yaitu sumber satu dengan lainnya cocok, atau satu sumber dengan lainnya tidak cocok namun tidak bertentangan, atau satu sumber dengan sumber lainnya bertentangan. Kesimpulan akhir dapat diambil jika peneliti sudah merasa datanya jenuh (saturated) dan setiap penambahan data hanya berarti ketumpangtindihan (redundant). Pada penelitian ini, triangulasi dilakukan dengan melakukan check dan recheck sejarah Kampung S dan sejarah TWA Sorong yang diceritakan oleh informan melalui pencocokan cerita seluruh informan dan melakukan pembandingan dengan 4 dokumen arsip terkait penguasaan tanah yang dimiliki masyarakat dan 33 arsip dokumen instansi pengelola terkait sejarah TWA Sorong hingga diperoleh kesimpulan akhir.

\section{HASIL DAN PEMBAHASAN}

\section{Fenomena Komunikasi: Konvergensi Simbolik}

Taman Wisata Alam Sorong pada mulanya adalah wilayah hasil penyerahan tanah ulayat 
masyarakat yang tinggal di antara Tg. Sorong dan S. Warmason kepada Pemerintah Daerah Dati II Sorong. Pada tahun 1977, 4 orang pemilik tanah ulayat atas nama HK, DO, SM dan EM melepaskan tanah seluas 614,2 ha kepada Pemerintah Daerah Dati II Sorong melalui Panitia Tanah A dengan surat Pernyataan Pelepasan Hak Atas Tanah Nomor: 001/PTA/1977 tanggal 31 Januari 1977.

Berdasarkan surat tersebut, melalui pertimbangan wilayah yang memiliki pemandangan indah sehingga perlu dibina secara khusus untuk dapat dimanfaatkan bagi kepentingan ilmu pengetahuan, pendidikan, kebudayaan, rekreasi dan pariwisata, Menteri Pertanian saat itu Prof. Ir. SH, melalui SK Menteri Pertanian Nomor: 397/Kpts/Um/5/1981 tanggal 7 Mei 1981 menunjuk wilayah dimaksud seluas 945,90 ha untuk dijadikan sebagai Taman Wisata Sorong.

Berbekal SK Menteri Pertanian tersebut, Balai PK VI Maluku-Irian Jaya beserta Panitia Tata Batas yang diketuai Bupati Sorong, melakukan penataan batas kawasan dan telah temu gelang sesuai dengan peta lampiran SK Menteri Pertanian Nomor: 397/Kpts/Um/5/1981 tanggal 7 Mei 1981 dan dibuktikan melalui Berita Acara Tentang Penataan Batas Hutan Wisata Sorong tanggal 6 Oktober 1981. Walaupun Kawasan Taman Wisata Sorong telah selesai dilakukan penataan batas, namun ternyata proses pengukuhan kawasannya terkendala karena dokumen penataan batas yang dikirimkan ke Pusat dianggap belum lengkap. Oleh sebab itu, proses pengukuhan kawasan Taman Wisata Sorong pada saat itu belum dapat dilanjutkan.

Status kawasan yang belum selesai proses penetapan batasnya ditambah adanya keberadaan hak ulayat yang masih kuat disertai dengan dinamika pembangunan daerah yang cukup pesat, membuat sebagian masyarakat mencoba melakukan klaim lahan yang telah ditunjuk sebagai Taman Wisata Sorong. Klaim pertama dilakukan oleh Saudara DOK dengan dikuasakan kepada Saudara LT yang mengajukan gugatan ke Pengadilan Negeri Sorong melalui gugatan Nomor 19/Pdt.G/48/PN.SRG tanggal 18 April 1998 dengan menggugat Bupati DATI II Sorong dan Kepala Dinas Kehutanan DATI II Sorong atas tanah seluas \pm 90 ha yang dianggap masuk ke dalam kawasan Taman Wisata Sorong.

Gugatan yang diajukan oleh Saudara DOK dikabulkan oleh Pengadilan Negeri Sorong melalui putusan Pengadilan Negeri Sorong Nomor 19/Pdt.G/ 1998/PN.SRG tanggal 23 Januari 1999. Namun demikian, tergugat masih mengambil langkah banding ke Pengadilan Tinggi Irian Jaya melalui Memori banding tanggal 5 juli 1999 terhadap putusan PN Sorong tanggal 23 Januari 1999 nomor 19/pdt.g/1998/PN.SRG dalam perkara perdata yang akhirnya dikabulkan oleh Pengadilan Tinggi Irian Jaya melalui Putusan Pengadilan Tinggi Irian Jaya Nomor 39/PDT/1999/PT.IRJA tanggal 19 Agustus 1999 yang membatalkan putusan Pengadilan Negeri Sorong Nomor 19/Pdt.G/1998/PN.SRG tanggal 23 Januari 1999. Secara lebih rinci proses gugatan TWA Sorong di Pengadilan disajikan dalam Tabel 1 .

Tabel 1. Proses Gugatan Batas TWA Sorong di Pengadilan

\begin{tabular}{|c|c|c|}
\hline No & Dokumen & Substansi \\
\hline 1 & $\begin{array}{l}\text { Gugatan DOK ke } \\
\text { Pengadilan Negeri } \\
\text { Sorong }\end{array}$ & $\begin{array}{l}\text { Duduk perkara: } \\
\text { 1. Penggugat memiliki tanah adat seluas } \pm 140 \text { ha di Jl. Sorong } \\
\text { Klamono Km.17 Kelurahan Aimas dengan batas: } \\
\text { Utara: Tanah adat keret M } \\
\text { Timur: Tanah adat keret KK } \\
\text { Selatan: Jl. PT. Intimpura/tanah adat keret O. } \\
\text { Barat: jl. Sorong Klamono. } \\
\text { 2. Tanah seluas } \pm 90 \text { ha dalam tanah penggugat adalah tanah sengketa } \\
\text { yang diambil/diduduki tergugat dengan melawan hukum: } \\
\text { Utara: tanah adat keret malaseme klablin } \\
\text { Timur: Sisa tanah adat penggugat } \\
\text { Selatan: sisa tanah penggugat/jlintimpura } \\
\text { Barat: jl.sorong klamono } \\
\text { 3. Tanah sengketa yang menjadi hutan lindung/wisata tidak pernah } \\
\text { dilepaskan sehingga tergugat telah melawan hukum. } \\
\text { 4. Tergugat telah masuk dan menguasai tanah tanpa adanya pelepasan } \\
\text { sehingga melawan hukum. } \\
\text { 5. Tergugat melarang penggugat masuk dan berkebun sehingga sangat }\end{array}$ \\
\hline
\end{tabular}




\begin{tabular}{|c|c|c|}
\hline No & Dokumen & Substansi \\
\hline & & $\begin{array}{l}\text { merugikan dan harus mengganti rugi sebesar } 4,5 \text { milyar. } \\
\text { 6. Penggugat takut tergugat menjual tanah sengketa karena harga jual } \\
\text { tinggi, letak strategis, dan sangat luas. }\end{array}$ \\
\hline 2 & $\begin{array}{l}\text { Putusan } \\
\text { Pengadilan Negeri } \\
\text { Sorong }\end{array}$ & 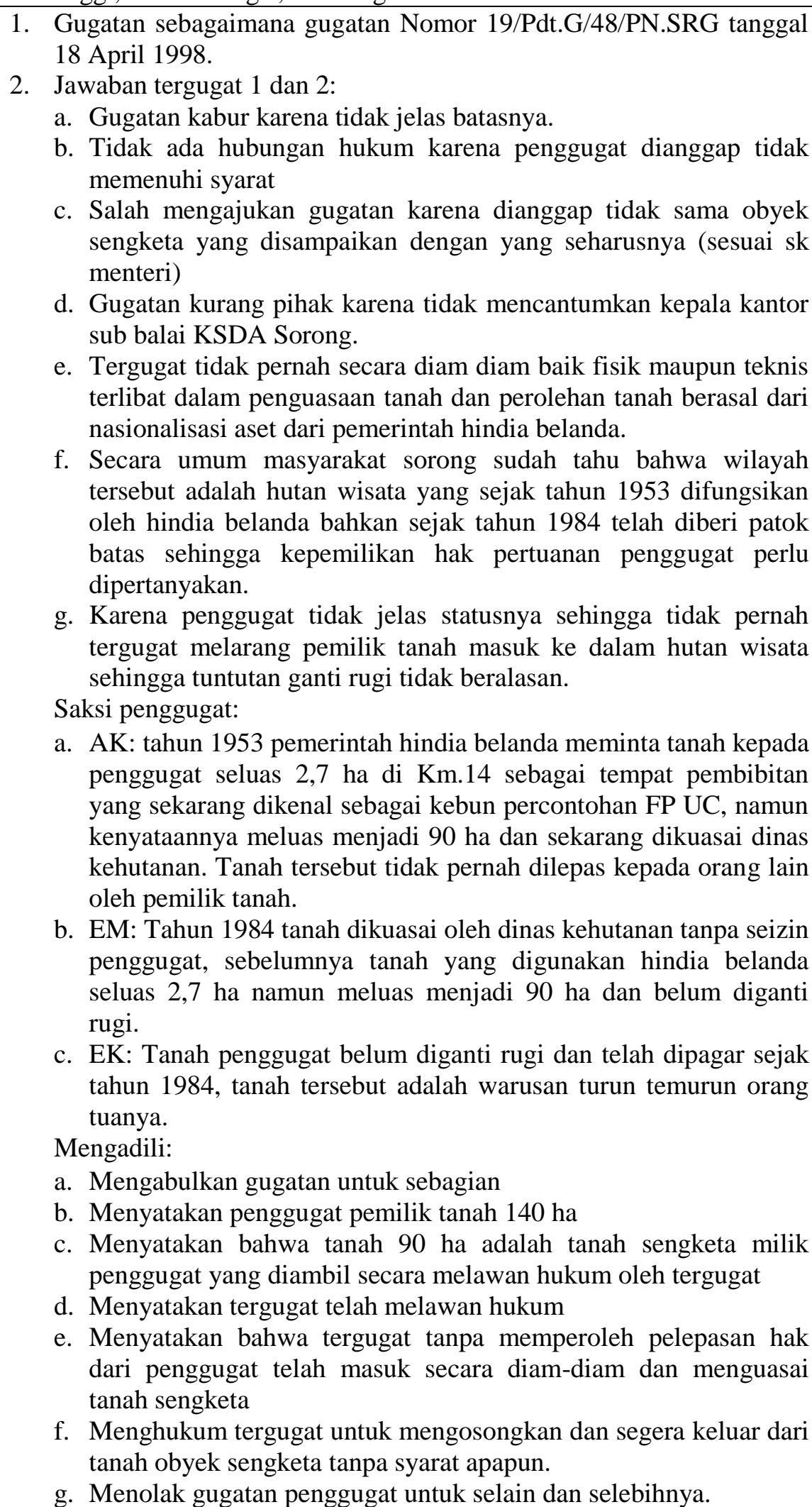 \\
\hline 3 & $\begin{array}{l}\text { Memori Banding } \\
\text { Pengelola }\end{array}$ & $\begin{array}{l}\text { Permohonan banding: } \\
\text { a. Keberatan pertama: fakta gugatan kurang pihak tidak } \\
\text { dipertimbangkan padahal secara teknis dan fungsional pengelola } \\
\text { hutan wisata adalah sub balai KSDA Sorong dan dinas kehutanan }\end{array}$ \\
\hline
\end{tabular}




\begin{tabular}{|c|c|c|}
\hline No & Dokumen & Substansi \\
\hline & & $\begin{array}{l}\text { sorong. } \\
\text { b. Keberatan kedua: Pertimbangan hukum hakim pertama hanya } \\
\text { berdasarkan interpretasi hakim tanpa memperhatikan adanya } \\
\text { hukum positif yang mengatur obyek sengketa. } \\
\text { c. Keberatan ketiga: keputusan berdasarkan persangkaan yang kuat } \\
\text { dari bukti-bukti penggugat mengesampingkan kedudukan dan } \\
\text { kualitas penggugat yang belum jelas asal-usulnya. } \\
\text { d. Keberatan keempat: dalam hukum acara perdata tidak perlu ada } \\
\text { keyakinan hakim. } \\
\text { e. Memohon agar membatalkan putusan pengadilan negeri sorong } \\
\text { nomor 19/pdt.g/1998/PN.SRG dan menolak seluruh gugatan } \\
\text { penggugat. }\end{array}$ \\
\hline 4 & $\begin{array}{l}\text { Putusan } \\
\text { Pengadilan Tinggi } \\
\text { Irian Jaya }\end{array}$ & $\begin{array}{l}\text { Tidak sependapat dengan putusan pengadilan negeri sorong: } \\
\text { a. Kedua pihak mengakui tanah sengketa adalah hutan lindung milik } \\
\text { pemerintah } \\
\text { b. Seharusnya sub balai KSDA Sorong sebagai pengelola juga ikut } \\
\text { digugat sehingga para pihak kurang lengkap } \\
\text { c. Putusan tidak dapat dipertahankan dan harus dibatalkan serta } \\
\text { menerima eksepsi tergugat }\end{array}$ \\
\hline
\end{tabular}

Sumber: Olahan Peneliti dari arsip internal BBKSDAPB

Selain gugatan dari Saudara DOK, beberapa klaim juga diajukan oleh masyarakat ke beberapa instansi yang terkait dengan Taman Wisata Sorong, yaitu seperti:

1. Permohonan pembebasan tanah oleh Saudara EM dan PM kepada Menteri Kehutanan dan Menteri Lingkungan hidup atas tanah di KM.14 yang dijadikan Taman Wisata Sorong melalui surat permohonan pembebasan kawasan hutan wisata alam tanggal 7 januari 1999.

2. Laporan masyarakat dari Keret OK kepada Menteri Kehutanan perihal pengambilan tanah masyarakat di Km.16 seluas \pm 90 ha yang diambil oleh Pemda DATI II Sorong, Dinas Kehutanan dan Sub Balai KSDA Irian Jaya I Sorong melalui surat laporan masyarakat atas masalah tanah adat milik keret OK yang diambil oleh Pemda Tk.II Sorong, Dinas Kehutanan Sorong dan Sub Balai KSDA Irian Jaya I Sorong tanggal 22 Maret 1999 dan sekaligus meminta untuk memperjelas selisih status tanah antara luas pelepasan tanah adat dengan luas penunjukan kawasan yang mencapai \pm 300 ha.

3. Penarikan kembali tanah adat yang telah diserahkan oleh keret $\mathrm{M}$ atas tanah yang menjadi Taman Wisata Sorong yang diwakili oleh EM dan PM kepada Bupati Sorong, Sub Balai KSDA Irian Jaya I Sorong dan Kepala BPN Sorong melalui surat keluarga besar keret M tanggal 16 april 1999.

Berbagai masalah klaim tanah di Taman Wisata Sorong yang kemudian berubah nama menjadi Taman Wisata Alam (TWA) Sorong yang belum menemui titik penyelesaian membuat munculnya perkampungan/pemukiman baru di dalam TWA Sorong dengan dibangunnya perumahan, fasilitas sosial dan umum, serta kegiatan usaha yang berada di dalam kawasan TWA Sorong. Dengan situasi yang telah terjadi, BBKSDAPB selaku pihak yang menerima pelimpahan wewenang pengelolaan TWA Sorong dari Pemerintah Daerah Dati II Sorong menemui hambatan dalam melakukan pengelolaan kawasan TWA.

Berawal dari adanya proses penetapan kawasan yang belum dapat dilakukan, kemudian munculnya gugatan masyarakat, adanya ketidaksepahaman luas TWA Sorong hasil penyerahan masyarakat dengan yang ditunjuk Menteri Pertanian, dan adanya proses gugatan masyarakat yang semula menang di Pengadilan Negeri Sorong kemudian kalah di Pengadilan Tinggi Irian Jaya serta didukung oleh kuatnya dominasi kepemilikan hak ulayat, membuat muncul dan berkembangnya perkampungan/ pemukiman baru di dalam dan sekitar TWA Sorong disertai adanya pemahaman baru yang terkonvergensi secara berbeda dengan pemahaman pengelola TWA Sorong mengenai batas kawasan. Fenomena tersebut menggambarkan adanya fenomena komunikasi konvergensi simbolik 
dalam konteks distorsi pemahaman batas kawasan TWA Sorong.

Teori konvergensi simbolik pada awalnya diilhami oleh riset Robert Bales mengenai komunikasi kelompok-kelompok kecil yang kemudian dikembangkan lebih lanjut oleh Ernest Bormann melalui penelitian-penelitian intensifnya sepanjang tahun 1970-an (Kartikawangi, 2013). Konvergensi simbolik secara sederhana dapat dimaknai sebagai suatu bentuk kekompakan kelompok yang dipacu oleh adanya fantasi yang diyakini bersama melalui pertukaran yang terus menerus sehingga menjadi suatu simbol bahkan identitas dari kelompok tersebut (Suryadi, 2010). Simbol yang telah diyakini bersama akan menumbuhkan rasa kesamaan, kesadaran dan kekompakan akan makna yang dimiliki dari suatu simbol melalui fantasi-fantasi yang diceritakan dan di dramatisasi. Fantasifantasi yang telah menjadi simbol akan membentuk seperti rantai fantasi dengan kohesi yang kuat sehingga hanya dengan sedikit pemantik yang muncul pada tema-tema fantasinya akan membangkitkan makna,ingatan bahkan emosional anggota kelompok tersebut (Elsakina, 2016).

Fantasi sendiri dalam teori ini bukan dimaknai sebagai cerita fiktif atau keinginan erotis melainkan mengarah pada cerita terhadap sesuatu yang telah terjadi, sedang atau akan terjadi dan diterima oleh suatu kelompok dengan pemaknaan yang sama (Mutiaz, 2019). Fantasi dapat berawal dari cerita berupa lelucon, guyonan, analogi, umpatan hingga pada level yang lebih lanjut mampu menjadi visi retoris yang mampu memompa semangat interaksi. Fantasi tersimbolkan dalam tematema tertentu yang telah diyakini bersama dalam suatu kelompok/ komunitas masyarakat. Dengan demikian dapat ditarik bahwa suatu wacana di dalam kelompok masyarakat setidaknya memiliki tematema fantasi yang memiliki makna, simbol serta proses-proses pertukaran dan dramatisasi yang dibangun oleh kelompok masyarakat tersebut sebagai sebuah konvergensi simbolik (Prasati \& Indriani, 2018).

Fenomena konvergensi simbolik dalam kasus TWA Sorong ditunjukkan melalui munculnya beberapa tema fantasi dalam pembicaraan dengan informan dari unsur masyarakat dan pengelola. Adapun konvergensi simbolik yang diperoleh disajikan dalam tabel 2 dan tabel 3.

Tabel 2. Konvergensi simbolik unsur masyarakat terhadap TWA Sorong

\begin{tabular}{|c|c|c|c|c|}
\hline Tema & Simbol & Makna & Dramatisasi & Rantai \\
\hline $\begin{array}{l}\text { Hutan Lindung* } \\
\text { *Masyarakat lebih } \\
\text { familiar menyebut } \\
\text { TWA dengan } \\
\text { hutan lindung }\end{array}$ & $\begin{array}{l}\text { Hutan yang } \\
\text { masih } \\
\text { bagus di } \\
\text { dalam } \\
\text { pagar* } \\
\text { *ada pagar } \\
\text { kawat yang } \\
\text { pernah } \\
\text { dibangun } \\
\text { masyarakat } \\
\text { dengan } \\
\text { pengelola lama } \\
\text { untuk } \\
\text { membatasi } \\
\text { lahan milik } \\
\text { DOK yang di } \\
\text { dalam TWA }\end{array}$ & $\begin{array}{l}\text { Hutan yang } \\
\text { dikelola } \\
\text { pemerintah } \\
\text { (BBKSDAPB) } \\
\text { tidak boleh } \\
\text { diganggu }\end{array}$ & $\begin{array}{l}\text { Masyarakat turut } \\
\text { menjaga } \\
\text { kelestarian hutan } \\
\text { lindung }\end{array}$ & $\begin{array}{l}\text { Cerita turun temurun } \\
\text { tentang wilayah } \\
\text { hutan lindung }\end{array}$ \\
\hline Tanah Ex-TWA & $\begin{array}{l}\text { Tanah di luar } \\
\text { pagar }\end{array}$ & $\begin{array}{l}\text { Tanah bekas } \\
\text { TWA/ bukan } \\
\text { tanah } \\
\text { kehutanan } \\
\text { hasil } \\
\text { kemenangan } \\
\text { DOK di }\end{array}$ & $\begin{array}{l}\text { Tanah di luar } \\
\text { pagar adalah } \\
\text { tanah DOK yang } \\
\text { menang gugatan } \\
\text { di pengadilan, } \\
\text { DOK adalah } \\
\text { pemilik hak }\end{array}$ & $\begin{array}{l}\text { Cerita turun temurun } \\
\text { tentang kemenangan } \\
\text { DOK di pengadilan }\end{array}$ \\
\hline
\end{tabular}




\begin{tabular}{|c|c|c|c|c|}
\hline Tema & Simbol & Makna & Dramatisasi & Rantai \\
\hline & & pengadilan & $\begin{array}{l}\text { ulayat yang } \\
\text { diakui oleh adat } \\
\text { setempat }\end{array}$ & \\
\hline $\begin{array}{l}\text { Tanah Hasil } \\
\text { Pembelian }\end{array}$ & $\begin{array}{l}\text { Kampung } \mathrm{S} \\
\text { dengan bukti } \\
\text { pembelian }\end{array}$ & $\begin{array}{l}\text { Kampung S } \\
\text { adalah } \\
\text { kampung yang } \\
\text { berdiri di atas } \\
\text { tanah Ex- } \\
\text { TWA hasil } \\
\text { pembelian dari } \\
\text { DOK yang ada } \\
\text { bukti } \\
\text { pembelian } \\
\text { tanahnya oleh } \\
\text { masyarakat } \\
\text { Kampung S }\end{array}$ & $\begin{array}{l}\text { Jika status tanah } \\
\text { tidak jelas maka } \\
\text { tidak mungkin } \\
\text { dibeli oleh } \\
\text { masyarakat } \\
\text { secara adat dan } \\
\text { mendapatkan } \\
\text { tanda bukti } \\
\text { pembeliannya }\end{array}$ & $\begin{array}{l}\text { Dokumen bukti } \\
\text { pembelian tanah }\end{array}$ \\
\hline Memiliki bukti & $\begin{array}{l}\text { Dokumen } \\
\text { pembelian tanah } \\
\text { ulayat DOK } \\
\text { seluas } 4 \text { hektar } \\
\text { oleh PK dan SK } \\
\text { sebagai wakil } \\
\text { masyarakat }\end{array}$ & $\begin{array}{l}\text { Kampung } S \\
\text { adalah } \\
\text { Kampung } \\
\text { legal yang } \\
\text { berdiri di atas } \\
\text { yang dibeli } \\
\text { secara sah oleh } \\
\text { masyarakat }\end{array}$ & $\begin{array}{l}\text { Dokumen } \\
\text { pembelian masih } \\
\text { disimpan rapi, } \\
\text { ditandatangani } \\
\text { oleh kepala desa } \\
\text { dan camat pada } \\
\text { waktu pembelian }\end{array}$ & $\begin{array}{l}\text { Dokumen bukti } \\
\text { pembelian tanah }\end{array}$ \\
\hline
\end{tabular}

Sumber: Olahan peneliti

Tabel 3. Konvergensi simbolik unsur pengelola terhadap TWA Sorong

\begin{tabular}{|c|c|c|c|c|}
\hline Tema & Simbol & Makna & Dramatisasi & Rantai \\
\hline TWA Sorong & $\begin{array}{l}\text { SK Menteri } \\
\text { Pertanian } \\
\text { tentang } \\
\text { penunjukan } \\
\text { TWA Sorong, } \\
\text { peta dan patok } \\
\text { batas }\end{array}$ & $\begin{array}{l}\text { Wilayah yang } \\
\text { dikelola } \\
\text { BBKSDAPB } \\
\text { mencakup } \\
\text { yang tertuang } \\
\text { pada peta } \\
\text { kawasan dan } \\
\text { termasuk tanah } \\
\text { Kampung S } \\
\text { dan tanah } \\
\text { obyek gugatan } \\
\text { DOK (yang } \\
\text { dianggap Ex- } \\
\text { TWA) }\end{array}$ & $\begin{array}{l}\text { UPT yang } \\
\text { mendapat } \\
\text { wewenang untuk } \\
\text { mengelola } \\
\text { kawasan } \\
\text { konservasi di } \\
\text { Papua Barat }\end{array}$ & $\begin{array}{l}\text { Arsip internal dan } \\
\text { publikasi informasi } \\
\text { kawasan }\end{array}$ \\
\hline $\begin{array}{l}\text { Pengukuhan } \\
\text { kawasan }\end{array}$ & $\begin{array}{l}\text { Patok batas dan } \\
\text { berita acara tata } \\
\text { batas }\end{array}$ & $\begin{array}{l}\text { Telah } \\
\text { dilakukan } \\
\text { penataan } \\
\text { kawasan }\end{array}$ & $\begin{array}{l}\text { Tata batas telah } \\
\text { dilakukan tetapi } \\
\text { prosesnya belum } \\
\text { selesai mencapai } \\
\text { penetapan }\end{array}$ & $\begin{array}{l}\text { Arsip internal/ surat } \\
\text { menyurat }\end{array}$ \\
\hline
\end{tabular}




\begin{tabular}{|c|c|c|c|c|}
\hline Tema & Simbol & Makna & Dramatisasi & Rantai \\
\hline $\begin{array}{l}\text { Kampung di } \\
\text { dalam kawasan }\end{array}$ & $\begin{array}{l}\text { Kampung yang } \\
\text { berada di dalam } \\
\text { patok batas }\end{array}$ & $\begin{array}{l}\text { Kampung } \\
\text { berdiri tanpa } \\
\text { izin (illegal) di } \\
\text { dalam } \\
\text { kawasan } \\
\text { konservasi }\end{array}$ & $\begin{array}{l}\text { Masyarakat telah } \\
\text { membuat } \\
\text { kampung di } \\
\text { dalam wilayah } \\
\text { TWA Sorong } \\
\text { dengan dasar } \\
\text { DOK menang } \\
\text { padahal kalah } \\
\text { dalam banding }\end{array}$ & Arsip internal \\
\hline $\begin{array}{l}\text { Pengelola } \\
\text { kawasan }\end{array}$ & $\begin{array}{l}\text { Kantor Balai } \\
\text { Besar KSDA } \\
\text { Papua Barat, } \\
\text { petugas penjaga } \\
\text { dan papan- } \\
\text { papan informasi }\end{array}$ & $\begin{array}{l}\text { TWA Sorong } \\
\text { memiliki } \\
\text { pengelola yang } \\
\text { sah }\end{array}$ & $\begin{array}{l}\text { Dilakukan } \\
\text { pengelolaan } \\
\text { kawasan baik } \\
\text { yang bersifat } \\
\text { teknis, } \\
\text { administratif } \\
\text { maupun } \\
\text { pembinaan } \\
\text { masyarakat } \\
\text { secara terus } \\
\text { menerus }\end{array}$ & $\begin{array}{l}\text { Surat menyurat, } \\
\text { hasil-hasil penelitian, } \\
\text { kegiatan-kegiatan } \\
\text { patroli, kegiatan kerja } \\
\text { sama pembangunan } \\
\text { TWA, pelaksanaan } \\
\text { upacara adat, } \\
\text { kegiatan sosialisasi } \\
\text { dan pemberdayaan } \\
\text { masyarakat setempat } \\
\text { serta kegiatan } \\
\text { pemulihan ekosistem }\end{array}$ \\
\hline
\end{tabular}

Sumber: Olahan peneliti

Konvergensi simbolik dalam perkembangannya telah menciptakan persepsi yang berbeda terhadap TWA Sorong yang diyakini oleh masyarakat Kampung S dengan pengelola kawasan sehingga menyebabkan terjadinya informasi yang tidak simetris (asymmetric information). Asymmetric information merupakan istilah yang sering digunakan dalam kajian bidang ilmu ekonomi dan bisnis namun demikian dapat dimaknai juga penggunaannya dalam konteks transaksi informasi pada kajian komunikasi pembangunan. Asymmetric information diartikan sebagai suatu kondisi di mana manager (agent) memiliki lebih banyak informasi atas prospek perusahaan dibandingkan dengan pemegang saham (principal) (Lisa, 2012). Pengertian tersebut dapat dimaknai sebagai adanya ketidaksamaan informasi yang dimiliki antara dua pihak atau lebih yang saling memiliki keterkaitan sehingga dalam pemaknaan dan pemanfaatan informasi terjadi ketidaksinkronan. Ketimpangan yang terjadi akan berimplikasi pada bagaimana kedua belah pihak bersikap atas informasi yang dimilikinya. Pada banyak situasi, asymmetric information telah menimbulkan konflik kepentingan dan hambatanhambatan dalam menjalankan suatu program dan kegiatan (Lisa, 2012). Dapat dicermati dari tabel 2 dan tabel 3 bahwa terdapat perbedaan mendasar persepsi masyarakat dengan pengelola mengenai batas dan luas TWA Sorong, status Kampung S serta keberadaan tanah Ex-TWA.

Asymmetric information yang terbentuk akibat konvergensi simbolik yang kuat memang tidak mudah untuk dilakukan penyimetrisan informasi karena berkaitan dengan faktor-faktor historis dan sosiologis yang telah membangun keyakinan atas informasi yang dipercayainya. Implikasi dari fenomena ini apabila tidak segera dilakukan langkah-langkah antisipatif, pelan tapi pasti dapat mengakibatkan munculnya kecenderungan kondisi legal tidak legitimate (LTL) pada kawasan TWA Sorong sebagaimana wilayahnya dianggap sah secara administrasi dan hukum sebagai kawasan yang dikelola pemerintah (legal) namun belum sepenuhnya diterima oleh masyarakat mengenai luas dan keberadaan batas-batas kawasannya (tidak legitimate).

Istilah LTL diperkenalkan oleh Kartodihardjo (2016) yaitu sebagai kondisi dimana kawasan hutan memiliki kondisi yang sah menurut hukum formal (legal) namun tidak diakui oleh para pihak di dalamnya (tidak legitimate). Situasi yang terjadi adalah pada umumnya, kawasan hutan yang telah dianggap sah secara administratif melalui proses penunjukan dan/atau penetapan kawasan, secara absolut telah dianggap sebagai pembenaran dalam melakukan tindakan-tindakan di dalamnya. 
Padahal, unsur pengakuan dan keberterimaan (legitimate) oleh para pihak yang berkaitan dengan kawasan tersebut terutama masyarakat di dalam dan/atau sekitarnya menjadi bagian penting dan tidak dapat dikesampingkan. Oleh sebab itu, penentuan keberlangsungan berbagai aktivitas dalam kawasan hutan tidak hanya berkaitan dengan unsur legal saja melainkan memerlukan adanya unsur legitimasi dari pihak-pihak yang berkaitan di dalamnya. Hal ini menjadi atensi penting bagi pengelola untuk menentukan langkah-langkah strategis dan sistematis dalam bentuk program dan kegiatan yang mampu mendorong percepatan penetapan kawasan TWA Sorong melalui proses partisipatif yang tetap mengakomodir konteks konvergensi simbolik keberadaan Kampung $S$ supaya tetap menjamin keberlangsungan kehidupan sosial, ekonomi dan budaya masyarakat secara berkelanjutan.

\section{Konstruksi Konvergensi Simbolik: Tradisi Oral, Sistem Kepemimpinan dan Hak Ulayat}

Fenomena konvergensi simbolik tidak serta merta muncul secara instan. Ada aspek yang mengonstruksi munculnya fenomena tersebut. Faktor-faktor yang memiliki kecenderungan membentuk konvergensi simbolik adalah masih berkembangnya tradisi oral (oral tradition) di masyarakat, sistem kepemimpinan adat yang diantut di Kampung S adalah sistem kepemimpinan campuran, dan masih kuatnya pengakuan terhadap hak ulayat (beschhikkingsrecht).

Perkembangan suatu peradaban pasti akan mewarisi tradisi lisan dan tulisan. Tradisi lisan merupakan segala wacana yang disampaikan secara lisan mengikuti cara atau adat istiadat yang telah membentuk pola dalam suatu masyarakat (Duija, 2005). Wacana yang terkandung dalam tradisi lisan dapat berupa mitos, cerita rakyat, legenda, dongeng, sejarah, silsilah dan sebagainya yang merupakan bagian dari interaksi sosial dari lisan ke lisan (Duija, 2005). Dengan demikian, sebagai bagian dari bentuk interaksi sosial yang tidak terdokumentasikan, tradisi lisan akan menimbulkan banyak versi dalam perkembangannya yang turun temurun. Tradisi ini umum berkembang di pedesaan atau perkampungan yang dalam transformasi perkembangannya lebih lambat dalam mengenal tradisi tulisan. Namun, perkembangannya, tradisi lisan ini juga memiliki peran penting dalam membangun narasi-narasi politik dan perlawanan terutama digunakan oleh kaum-kaum tertindas (Santoso, 2004). Tradisi lisan masih sangat kental terjadi di Kampung S. Seluruh informan sangat mengandalkan ingatannya dalam menuturkan sejarah kampung, adat dan budayanya. Hal ini serupa dengan hasil penelitian Suryawan (2015) yang menyebutkan bahwa budaya masyarakat Papua adalah tradisi oral, dan tumbuh subur di perkampungan yang menyebar dan menjadi keyakinan bersama untuk menjalani kehidupan. Faktor tradisi oral memiliki peran yang besar dalam konvergensi simbolik mengenai sejarah asal-usul lahan dan batas-batasnya untuk pendirian Kampung S yang ternyata terdapat perbedaan dengan yang diyakini oleh pengelola kawasan.

Masyarakat Kampung S merupakan masyarakat yang berlatar belakang Suku Maybrat walaupun berada dan tinggal di wilayah Suku Moi. Terdapat 12 marga Maybrat dan 4 marga pendatang dari suku lain yang tinggal di Kampung S dengan total penduduk sebanyak 400 jiwa dan 53 rumah. Kepercayaan masyarakat Kampung $S$ dalam hal kepemimpinan menganut sistim kepemimpinan campuran yaitu sistim yang dalam memilih pemimpin di kelompoknya tidak selalu berdasar garis keturunan melainkan dapat mengangkat siapa yang berjasa atau mampu mengatasi suatu masalah yang timbul pada kelompok tersebut. Terlihat pada pemilihan pemimpin di Kampung S, yang dipilih adalah PK dan SK selaku perwakilan masyarakat dalam membeli tanah dari DOK (masingmasing seluas 2 hektar) sebagai awal dibukanya lahan untuk dibangun Kampung S. Masyarakat menghormati dan selalu meminta pertimbangan pada hal-hal atau masalah yang berkaitan dengan Kampung kepada kedua pemimpin kampung tersebut. Gambaran kepemimpinan ini juga sesuai dengan penelitian Deda \& Mofu (2013) yang menyebutkan bahwa sistem kepemimpinan di Papua Barat pada umumnya terbagi menjadi 2, sistem kerajaan dianut oleh Orang-Orang Kawe, Maya, Moi dan Baser di Raja Ampat, Orang-Orang Iha, Onin dan Mbaham di Fak-Fak, dan Orang-Orang Kowiai, Irarutu, Mairasi, Buruai, Kamberau dan Kamoro di Kaimana dan Bintuni, sedangkan sistem campuran banyak dianut oleh Orang-Orang Maybrat. Faktor kepemimpinan ini juga memiliki peran penting dalam pembentukan konvergensi simbolik karena masyarakat cenderung "hanya" mendengar dan mengikuti apa yang disampaikan oleh pemimpinnya termasuk mengenai sejarah asal-usul lahan dan batas-batasnya.

Masyarakat Papua pada umumnya masih mengakui adanya sistem penguasaan tanah secara komunal yang diakui secara adat yaitu sistem hak ulayat (beschhikkingsrecht). Sebagaimana 
disampaikan Deda \& Mofu (2013) hak ulayat atau hak patuanan diakui, dikenal dan masih kuat pemilikannya di Papua Barat dan merupakan hak yang sangat tua dan asal mulanya bersifat keagamaan "religio-magis". Hak ini bahkan diakui juga oleh Pemerintah Kabupaten Sorong yang secara khusus masuk ke dalam Peraturan Daerah Nomor 10 tahun 2017 tentang Pengakuan dan Perlindungan Masyarakat Hukum Adat Moi di Kabupaten Sorong. Sebagaimana hasil penelitian Mutiono (2020), lahan TWA Sorong secara adat terbagi ke dalam kepemilikan ulayat 3 marga yaitu Marga O, Marga Ma dan Marga Me (semua berupa inisial) sehingga ketiga marga tersebut masih memiliki kuasa secara adat terhadap wilayah lahan yang menjadi hak pertuanannya. Hak patuanan yang merupakan hak tertua dan masih diakui secara luas oleh masyarakat asli Papua membuat masyarakat perkampungan pada umumnya lebih percaya dan lebih takut kepada pemilik hak ulayat dibandingkan pemilik hak-hak atas tanah selain hak ulayat bahkan dalam banyak hal seperti diungkap Griapon \& Ma'rif (2016), hak patuanan ini dapat menjadi kendala dalam proses-proses pembangunan yang dilakukan oleh pemerintah. Faktor hak ulayat atau patuanan ini juga memiliki peran penting terbentuknya konvergensi simbolik karena masyarakat Kampung S yang merupakan tipe masyarakat perkampungan lebih mengikuti dan mempercayai informasi yang diberikan oleh pemilik hak ulayat yang mana Kampung $\mathrm{S}$ berdiri di atas tanah ulayat Marga $\mathrm{O}$ yang notabene pemilik utamanya adalah DOK.

\section{KESIMPULAN}

Dari hasil analisis yang telah dilakukan, dapat disimpulkan bahwa fenomena komunikasi yang muncul dalam kasus yang diungkap di TWA Sorong adalah fenomena komunikasi konvergensi simbolik yang menyebabkan terjadinya informasi tidak simetris mengenai batas dan luas TWA Sorong, status Kampung S dan keberadaan tanah Ex-TWA. Hal tersebut juga dapat berdampak pada terjadinya kondisi legal tidak legitimate. Konvergensi simbolik pada masyarakat Kampung S terhadap TWA Sorong dikonstruksi oleh beberapa faktor diantaranya tradisi oral yang masih umum berkembang di Kampung S, sistem kepemimpinan campuran yang dianut di Kampung S, dan masih kuatnya pada pengakuan keberadaan hak ulayat di TWA Sorong.

Memperhatikan adanya fenomena konvergensi simbolik, tema-tema fantasi yang berhubungan dengan batas dan luas kawasan TWA, keberadaan Kampung $S$ dan pemahaman terhadap tanah ExTWA yang diyakini oleh masyarakat harus menjadi atensi bagi penyuluh kehutanan di BBKSDAPB untuk perlahan-lahan melakukan pendekatan dan memberikan pemahaman kepada masyarakat Kampung S dan Marga $\mathrm{O}$ mengenai situasi kontekstual TWA Sorong hubungannya dengan rekonstruksi batas kawasan TWA Sorong. Konsep pengelolaan "keterlanjuran" perlu dilakukan dengan memperhatikan kondisi yang ada di lapangan yang nyata-nyata tidak mungkin untuk melakukan pemindahan kampung beserta relasi sosial, ekonomi dan budaya yang sudah terbentuk serta juga memperhatikan bahwa adanya kemauan masyarakat untuk terbuka berdialog bahkan turut mengakui dan menjaga keberadaan "hutan lindung" yang disimbolkan berada di dalam pagar kawat. Oleh sebab itu, proses rekonstruksi batas kawasan TWA Sorong sebaiknya segera dilakukan melalui dialog partisipatif berkenaan dengan luas toleransi yang bisa diterima oleh BBKSDAPB secara rasionalitas hukum yang mengikat proses pengukuhan kawasan TWA Sorong serta dapat diterima juga oleh masyarakat Kampung $\mathrm{S}$ dan Marga $\mathrm{O}$ dalam mengakomodir ruang sosial, budaya dan penghidupan masyarakat setempat sehingga mereka juga akan terbuka untuk turut membantu dalam menjaga kelestarian TWA Sorong dengan batas baru yang ditetapkan secara partisipatif.

\section{UCAPAN TERIMA KASIH}

Terima kasih diucapkan kepada Balai Besar Konservasi Sumber Daya Alam Papua Barat Direktorat Jenderal Konservasi Sumber Daya Alam dan Ekosistem Kementerian Lingkungan Hidup dan Kehutanan Republik Indonesia yang telah mendukung dan memfasilitasi seluruh proses penelitian mulai dari proses perencanaan penelitian, pengumpulan data hingga proses konfirmasi dan klarifikasi hasil temuan-temuan yang diperoleh baik melalui diskusi-diskusi personal maupun dalam pertemuan ilmiah yang pernah diselenggarakan. Terkhusus juga disampaikan terima kasih kepada Kepala Balai Besar KSDA Papua Barat yang telah memberikan izin dalam pelaksanaan penelitian serta penulisan hasil penelitian ini untuk dipublikasikan ke dalam jurnal ilmiah. 


\section{DAFTAR PUSTAKA}

Anakotta, R., Aiman, \& Solehun. (2019). Akulturasi Masyarakat Lokal dan Pendatang di Papua Barat. Jurnal Antropologi: Isu-Isu Sosial Budaya, 21(1), 29-37.

Cahyono, E. (2013). Eksklusi Atasnama Konservasi (Studi Kasus Masyarakat Sekitar/ Dalam Kawasan Taman Nasional Ujungkulon Banten). Sosiologi Reflektif, 8(1), 209-245.

Darmadi, H. (2014). Metode Penelitian Pendidikan dan Sosial: Teori Konsep Dasar dan Implementasi. Penerbit Alfabeta Bandung.

Deda, A. J., \& Mofu, S. S. (2013). Masyarakat Hukum Adat Dan Hak Ulayat Di Provinsi Papua Barat Sebagai Orang Asli Papua Ditinjau Dari Sisi Adat Dan Budaya: Sebuah Kajian Etnografi Kekinian. Jurnal Ilmiah Etnografi Papua, 1(1), 76-87.

Duija, I. N. (2005). Tradisi Lisan, Naskah dan Sejarah: Sebuah Catatan Politik Kebudayaan. Jurnal Wacana, 7(2), 111-124.

Elsakina, R. F. (2016). Konvergensi Simbolik dalam Komunikasi Kelompok Komunitas Stand Up Indo Pekanbaru. Jom Fisip, 3(2), 1-14.

Griapon, K. V., \& Ma'rif, S. (2016). Pola Penerapan Hukum Adat dalam Penyelenggaraan Pembangunan di Wilayah Pembangunan III Grime Kabupaten Jayapura-Papua. Jurnal Wilayah Dan Lingkungan, 4(1), 13-28. https://doi.org/10.14710/jwl.4.1.13-28

Hadiyanto. (2008). Komunikasi Pembangunan Partisipatif: Sebuah Pengenalan Awal. Jurnal Komunikasi Pembangunan, 6(2), 80-88. https://doi.org/10.29244/jurnalkmp.6.2.\%p

Kartikawangi, D. (2013). Teori Konvergensi Simbolis (Symbolic Convergence Theory) dalam Kajian Pustaka. InterAct-Journal on Communication, 2(2), 71-81. https://doi.org/http://dx.doi.org/10.36388\%2Fia.v2i2.748

Kartodihardjo, H. (2016). Diskursus dan Kebijakan Institusi Politik Kawasan Hutan: Menelusuri Studi Kebijakan dan Gerakan Sosial Sumber Daya Alam di Indonesia. IPB Press.

Lisa, O. (2012). Asimetri Informasi Simetri Informasi dan Manajemen Laba. Jurnal WIGA, 2(1), 42 49. https://media.neliti.com/media/publications/36615-ID-asimetri-informasi-dan-manajemenlaba-suatu-tinjauan-dalam-hubungan-keagenan.pdf

Mutiaz, I. R. (2019). Konstruksi Realitas Simbolik Generasi Milenial Melalui Tema Fantasi Selebgram Di Media Sosial. Jurnal Sosioteknologi, 18(1), 113-129. https://doi.org/10.5614/sostek.itbj.2019.18.1.9

Mutiono. (2020). Fenomena Sosial Masyarakat Sekitar Kawasan Konservasi: Studi Kasus Masyarakat Penyangga Kawasan Taman Wisata Alam (TWA) Sorong Provinsi Papua Barat. Jurnal Penelitian Administrasi Publik, 6(1), 55-71.

Mutiono, Sarwoprasodjo, S., Soedomo, S., \& Budianto, H. (2018). Komunikasi Pedagogis Pendidikan Tinggi Kehutanan Dalam Perspektif Kritis. Jurnal Komunikasi Pembangunan, 16(2), 172-185. https://doi.org/10.29244/jurnalkmp.16.2.172-185

Prasati, D., \& Indriani, S. S. (2018). Konvergensi Simbolik Tentang Percakapan Remaja Laki-Laki Dalam Media Sosial Group LINE. Jurnal Komunikasi Hasil Pemikiran Dan Penelitian, 4(1), 18.

Santoso, H. (2004). Perlawanan di Simpang Jalan: Kontes Harian di Desa-Desa Sekitar Hutan di Jawa. Penerbit Damar. 
Suryadi, I. (2010). Teori konvergensi simbolik. JURNAL ACADEMICA Fisip Untad, 2(2), 426-437. jurnal.untad.ac.id/jurnal/index/.php/academica/article/view/2305/1494

Suryawan, I. N. (2015). Identitas yang Terpecah dan Peluang Transformasi Sosial Budaya di Tanah Papua. Journal of Local Culture, 2(1), 16-41.

Wiratno. (2018). Sepuluh Cara Baru Kelola Kawasan Konservasi di Indonesia: Membangun Organisasi Pembelajar. Direktorat Jenderal KSDAE. 